\title{
Hubungan Stres dengan Kualitas Hidup pada Penderita DM Tipe 2 di Kabupaten Poso
}

\section{The relationship between stress and quality of life in people with type 2 diabetes in Poso district}

\author{
Dwi Debi Tampa'i ${ }^{1 *}$, Ferdy Lainsamputty ${ }^{2}$, Yunike Katiandagho ${ }^{3}$ \\ 1,2,3 Program Studi S1 Keperawatan, STIKES Husada Mandiri Poso, Sulawesi Tengah, Indonesia \\ *Corresponding author \\ Email: debbytampai123@gmail.com
}

\begin{tabular}{|c|c|}
\hline & $A b s t r a c t$ \\
\hline $\begin{array}{l}\text { Keyword: } \\
\text { Quality of Life DM } \\
\text { type 2, Stress }\end{array}$ & $\begin{array}{l}\text { Background: DM and stress are closely related especially to events in urban areas. Life } \\
\text { pressures and unhealthy lifestyles are very influential, coupled with increasingly rapid } \\
\text { technological advances and various diseases that are being suffered causing a decrease } \\
\text { in a person's condition so that it triggers stress. Psychological disorders such as } \\
\text { depression and stress that are common in the DM population, require proper treatment } \\
\text { because they cause a drastic reduction in quality of life. Objective: This research was } \\
\text { conducted to determine the relationship between stress and quality of life in patients with } \\
\text { type } 2 \text { diabetes. Method: This research is a correlation analytic type with a cross } \\
\text { sectional approach. The population in this study were all patients with type } 2 \text { DM in } \\
\text { outpatients in Poso Regional Hospital as many as } 2023 \text { people, with a total sample of } \\
\text { 137 people. The sampling technique used was purposive sampling. Data were collected } \\
\text { using a Depression Anxiety Stress Scale } 42 \text { (DASS 42) and WHOQOL-BREF } \\
\text { questionnaire. Descriptive statistics and bivariate analysis (mann whitney, kruskalwallis } \\
\text { and Spearman Rank) are used to look for relationships between variables. Results: Age } \\
\text { related to quality of life in the physical domain (p<0.05), duration (long suffering from } \\
\text { type-2 diabetes mellitus) was associated with quality of life in the physical domain } \\
\text { (p<0.01), stress had no relationship when associated with all quality-of-life domains. } \\
\text { (p<0.05). Conclusion: There is no relationship between stress and quality of life in type } \\
2 \text { DM patients. }\end{array}$ \\
\hline
\end{tabular}
tipe 2,

Stres
Kata kunci :

Kualitas hidup DM \begin{abstract}
A B S T R A K
Latar belakang: DM dan stres berhubungan erat terutama dengan kejadian di daerah perkotaan. Tekanan kehidupan dan gaya hidup tidak sehat sangat berpengaruh, ditambah dengan kemajuan teknologi yang semakin pesat dan berbagai penyakit yang sedang diderita menyebabkan penurunan kondisi seseorang sehingga memicu terjadinya stres. Gangguan psikologis seperti depresi dan stres yang umum terjadi pada populasi DM, membutuhkan penanganan yang tepat karena menimbulkan penurunan drastis kualitas hidup. Tujuan: Penelitian ini dilakukan untuk mengetahui hubungan antara stres dengan kualitas hidup pada penderita DM tipe 2. Metode: Penelitian ini berjenis Analitik korelasional dengan pendekatan potong lintang atau cross sectional. Populasi pada penelitian ini adalah seluruh pasien DM tipe 2 di rawat jalan RSUD Poso sebanyak 2023 jiwa, dengan jumlah sampel 137 orang. Teknik pengambilan sampel yang digunakan adalah purposive sampling. Data dikumpulkan menggunakan kuesioner Depression Anxiety Stress Scale 42 (DASS 42) dan WHOQOL-BREF. Statistik deskriptif dan analisa bivariat (mann whitney, kruskalwallis dan Spearman Rank) digunakan untuk mencari hubungan antar variabel. Hasil: Umur berhubungan kualitas hidup domain fisik $(\mathrm{p}<0,05)$, durasi (lama Menderita DM tipe-2) berhubungan dengan kualitas hidup domain fisik $(\mathrm{p}<0,01)$, stress tidak memiliki hubungan ketika dikaitkan dengan semua domain kualitas hidup ( $\mathrm{p}<0,05)$. Kesimpulan: Tidak terdapat hubungan antara stres dengan kualitas hidup pada penderita DM tipe 2
\end{abstract}

How To Cite: Tampa'i, D.D., Lainsamputty, F., \& Katiandagho, Y. 2021. Hubungan Stres dengan Kualitas Hidup pada Penderita DM Tipe 2 di Kabupaten Poso Journal of Islamic Medicine. 5(2),141-155.https://doi.org/10.18860/jim.v5i2.1318

Copyright (c) 2021 


\section{LATAR BELAKANG}

Diabetes melitus (DM) merupakan salah satu penyakit dengan prevalensi meningkat pesat setiap tahunnya di seluruh dunia. Angka Kematian dengan penyakit ini sebesar $43 \%$ yang terjadi sebelum umur 70 tahun. Pada tahun 2014, 422 juta orang di dunia menderita DM, dengan prevalensi $8,5 \%$ pada populasi dewasa. Selama 3 tahun terakhir terjadi peningkatan prevalensi diabetes dan lebih dari $80 \%$ mortalistasnya terjadi di negara berpenghasilan menengah ke bawah. ${ }^{1}$ Indonesia masuk dalam urutan ke tujuh negara dengan penderita DM terbanyak dengan jumlah 10,1 juta jiwa. Sulawesi Tengah merupakan salah satu provinsi di Indonesia yang masuk dalam posisi pertama dari empat tertinggi prevalensi yang terdiagnosis oleh dokter sebanyak $3,7 \%{ }^{2}$

Banyak penderita tidak menyadari telah mengidap DM, karena gejalanya berlangsung progresif secara perlahan. Penderita biasanya baru menyadari setelah mereka mengalami berbagai komplikasi dan didiagnosis oleh dokter. Berbagai reaksi muncul setelah penderita tahu mengidap penyakit ini, mulai dari perasaan takut, cemas, depresi, marah bahkan sampai memberontak, serta stres. ${ }^{3}$ Penderita DM memiliki tingkat kecemasan dan stres yang tinggi, yang berkaitan dengan potensi terjadinya komplikasi serius dan terapi yang harus dijalani seperti diet atau pengaturan makan, kontrol gula darah, konsumsi obat, olahraga dan lain-lain yang harus dilakukan sepanjang hidupnya. ${ }^{4}$

Stress dapat memberi dampak secara total pada individu yaitu terhadap fisik, psikologis, intelektual, sosial dan spiritual, hingga dapat mengancam keseimbangan fisiologis. ${ }^{5}$ Penderita DM yang berada dalam keadaan stres sering kurang memprioritaskan kesehatan dan kontrol penyakit yang harus dijalankannya, hingga menyebabkan kontrol glikemik tidak terkendali. Kondisi hiperglikemia berdampak buruk terhadap luaran klinis karena dapat menyebabkan gangguan fungsi imun, lebih mudah terkena infeksi, peningkatan inflamasi, perburukan sistem kardiovaskular, trombosis, disfungsi endotel dan kerusakan otak. ${ }^{6}$

Penelitian sebelumnya menyebutkan bahwa stres pada penderita DM tipe 2 dapat meningkatkan kadar glukosa melalui mekanisme peningkatan stimulus simpatoadrenal, yaitu hubungan fisiologis antara sistem saraf simpatis dan medula adrenal dan sangat penting dalam respon fisiologis suatu organisme terhadap rangsangan luar. ${ }^{7}$ Hidup dengan diabetes yang menyebabkan stres akan menimbulkan efek pada kualitas hidup. ${ }^{4}$

Meningkatkan kualitas hidup merupakan tujuan utama dalam perawatan penderita DM tipe 2 dan sebisa mungkin kualitas hidup yang baik harus dipertahankan. ${ }^{8}$ Kualitas hidup yang buruk akan semakin memperburuk kondisi suatu penyakit, begitu pula sebaliknya, suatu penyakit dapat menyebabkan terjadinya penurunan kualitas hidup seseorang, terutama penyakit kronis yang sangat sulit disembuhkan salah satunya seperti DM. Bagi pengidap penyakit DM mempunyai pengaruh negatif terhadap kualitas hidup penderitanya walaupun dengan tanpa komplikasi. Gangguan psikologis seperti depresi dan stres yang umum terjadi pada populasi DM, membutuhkan penanganan yang tepat karena menimbulkan penurunan drastis kualitas hidup. ${ }^{9}$

Setiap pasien DM umumnya akan mengalami perasaan stres yang berkepanjangan, hingga berlanjut menjadi memperberat keadaan penyakit. ${ }^{10}$ Penderita DM di Indonesia cenderung meningkat dari tahun ke tahun, menunjukkan bahwa penyakit ini adalah ancaman serius dalam ranah kesehatan nasional. Beberapa penelitian sebelumnya telah mengidentifikasi hubungan kualitas hidup dan faktor psikologis seperti stres pada pasien DM tipe 2. Namun, informasi terkait variabel-variabel ini di daerah suburban Indonesia, seperti di Kabupaten Poso masih sangat terbatas. Oleh karenanya, penting untuk mengetahui hubungan keduanya bersama faktor-faktor 
lain untuk menemukan hal-hal yang berpotensi menurunkan atau meningkatkan kualitas hidup pasien. Berdasarkan hal inilah, maka peneliti tertarik untuk melakukan penelitian yang berjudul hubungan stres dan kualitas hidup pada penderita DM tipe 2 di Kabupaten Poso.

\section{METODE}

Desain penelitian yang digunakan dalam penelitian ini adalah deskriptif korelasi dengan menggunakan pendekatan crosssectional. Populasi dalam penelitian ini adalah Pasien Rawat Jalan yang menderita DM tipe 2 di Rumah Sakit Umum Daerah Poso dengan jumlah sampel sebesar 139 responden. Penentuan sampel dengan menggunakan teknik purposive sampling dengan kriteria inklusi yaitu a) Pasien yang terdiagnosa penyakit DM tipe 2 oleh dokter ; b) Berusia diatas 18 tahun saat dilakukan penelitian; dan c) Dapat berkomunikasi dengan baik dalam bahasa Indonesia. Data diperoleh dengan menggunakan kuesioner dan dianalisis dengan uji Statistik yaitu Mann Whitney, Kruskal Wallis dan Spearman Rank dengan menggunakan program SPSS.

\section{HASIL PENELITIAN}

\section{Gambaran Data Demografi dan Karakteristik Penyakit Responden}

Mayoritas responden berstatus menikah sebanyak 128 orang $(92,1)$, dan duda/janda 11 orang $(7,9)$. Sebagian besar responden mempunyai tingkat pendidikan dari yang terbanyak yaitu : SMA/Sederajat sebanyak 63 responden (45,3), PT sebanyak 41 responden (29,5), SMP sebanyak 23 responden (16,5), SD sebanyak 11 responden $(7,9)$ dan Tidak bersekolah 1 responden $(7)$.

Data karakteristik penyakit yaitu durasi terdiagnosis DM tipe 2, jumlah komorbiditas, pengobatan, dan jumlah obat yang digambarkan pada tabel 1 Hasil penelitian ini menunjukkan durasi rata-rata responden 6,08 $(\mathrm{SD}=4,72)$, dengan durasi minimal 2 tahun dan maksimal 36 tahun. Jumlah ratarata komorbiditas yang digambarkan pada tabel 1 yaitu 0,58 (SD 0,55). jumlah obat DM tipe 2 yang digunakan adalah 1,06 (SD = $0,24)$, dua jenis golongan obat yang digunakan responden terbanyak yaitu suntikan insulin sebanyak sembilan puluh lima responden $(68,3 \%)$ dan peningkat sensitivitas terhadap insulin sebanyak lima puluh satu responden $(36,7 \%)$.

\section{Gambaran Stres}

Gambaran skor stres dari responden ditampilkan pada Tabel 2. Menggambarkan setiap pernyataan pada kuesioner stres dan kategori stres yang diperoleh responden. Jumlah terbanyak untuk kategori jawaban tidak pernah dialami (Skor 1) yaitu pada item pernyataan "Saya menemukan diri saya menjadi tidak sabar ketika mengalami penundaan (misalnya: kemacetan lalu lintas, menunggu sesuatu" dengan jumlah responden yang menjawab adalah 65 responden $(46,8 \%)$ dan untuk kategori jawaban sering dialami (skor 3) terbanyak yaitu pada item pernyataan"saya menemukan diri saya mudah gelisah" dengan jumlah responden yang menjawab adalah 34 responden (24,5\%). Kemudian untuk kategori stres dengan frekuensi tertinggi yaitu stres sedang sebanyak 55 responden $(39,6 \%)$ sedangkan stres berat merupakan kategori terendah sebanyak 24 responden $(17,3 \%)$.

\section{Gambaran Kualitas Hidup Responden}

Pada Tabel 3 menunjukkan tentang gambaran kuaitas hidup pada responden sesuai hasil pengukuran menggunakan kuesioner WHOQOL-BREF. Domain fisik memiliki rata-rata 56,86 $(\mathrm{SD}=10,02)$, sedangkan pada domain psikologis terdapat rata-rata 54,96 $(\mathrm{SD}=11,06)$. Domain sosial memiliki ratarata 55,81 $(\mathrm{SD}=14,10)$ dan domain lingkungan mencapai rata-rata 58,77 $(\mathrm{SD}=11,12)$. Terdapat 2 pertanyaan yang tidak termasuk dalam 4 domain kualitas hidup di atas. Pertanyaan tentang kualitas hidup secara keseluruhan memiliki rata-rata 3,35 $(\mathrm{SD}=0,68)$. Sementara itu pertanyaan tentang kesehatan umum memiliki rata-rata $3,20(\mathrm{SD}=0,67)$. 
Tabel 1. Data Demografi dan Karakteristik Penyakit dari Responden ( $=139)$

\begin{tabular}{|c|c|c|c|c|}
\hline Variabel & Kategori & n (\%) & Rata-rata \pm SD & Min - Maks \\
\hline Umur & & & $58,0 \pm 9,50$ & $31-84$ \\
\hline \multirow[t]{2}{*}{ Jenis Kelamin } & Laki - Laki & $33 \quad(23,7)$ & & \\
\hline & Perempuan & $106(76,3)$ & & \\
\hline \multirow[t]{2}{*}{ Status pernikahan } & Menikah & $128 \quad(92,1)$ & & \\
\hline & Duda/Janda & $11(7,9)$ & & \\
\hline \multirow[t]{5}{*}{ Pendidikan } & Tidak bersekolah & $1 \quad(0,7)$ & & \\
\hline & SD & $11(7,9)$ & & \\
\hline & SMP & $23(16,5)$ & & \\
\hline & SMA/Sederajat & $63(45,3)$ & & \\
\hline & PT & $41(29,5)$ & & \\
\hline Durasi (Tahun) & & & $6,08 \pm 4,72$ & $2-36$ \\
\hline Jumlah Komorbiditas & & & $0,58 \pm 0,55$ & $0-2$ \\
\hline Nol & & $62(44,6)$ & & \\
\hline Satu & & $73(52,5)$ & & \\
\hline Dua & & $4(2,9)$ & & \\
\hline \multirow[t]{4}{*}{ Komorbiditas } & Penyakit ginjal & $4(2,9)$ & & \\
\hline & Penyakit paru & $4(2,9)$ & & \\
\hline & Gangguan pencernaan & $5(3,6)$ & & \\
\hline & Penyakit otot dan tulang & $4(2,9)$ & & \\
\hline Penyakit lain & & $64(45,3)$ & & \\
\hline \multirow[t]{9}{*}{ Keterangan lain-lain } & Hipertensi & $20(14,4)$ & & \\
\hline & Kolestrol & $11(7,9)$ & & \\
\hline & Katarak & $6(4,3)$ & & \\
\hline & Jantung & $4(2,9)$ & & \\
\hline & Asam urat & $11(7,9)$ & & \\
\hline & Maag & $9(6,5)$ & & \\
\hline & Asma & $1(0,7)$ & & \\
\hline & $\mathrm{SNH}$ & $1(0,7)$ & & \\
\hline & Cistitis & $1(0,7)$ & & \\
\hline \multirow[t]{4}{*}{ Pengobatan } & PSI & $1(0,7)$ & & \\
\hline & PSTI & $51(36,7)$ & & \\
\hline & SI & $95(68,3)$ & & \\
\hline & PG & $1(0,7)$ & & \\
\hline Jumlah Obat & & & $1,06 \pm 0,24$ & $1-2$ \\
\hline Satu & & $130 \quad(93,5)$ & & \\
\hline Dua & & $9(6,5)$ & & \\
\hline
\end{tabular}

*Catatan : SD = Sekolah Dasar; SMP =Sekolah Menengah Pertama; SMA = Sekolah Menengah Atas; PT = Perguruan Tinggi, PSI = Peningkat Sekresi Insulin, PSTI = Penghambat sesitivitas terhadap insulin, SI = Suntikan insulin, $\mathrm{PG}=$ Penghambat Glukoneogenesis. 
Tabel 2. Total DASS 14 dan Skor Setiap Item Pertanyaan (N=139)

\begin{tabular}{|c|c|c|c|c|c|c|c|}
\hline \multirow[t]{2}{*}{ No } & \multirow[t]{2}{*}{ Item } & \multirow[t]{2}{*}{$\begin{array}{c}\text { Rata-rata } \\
\pm \text { SD }\end{array}$} & \multicolumn{4}{|c|}{ n $(\%)$} & \multirow[t]{2}{*}{$\begin{array}{l}\text { Min- } \\
\text { Maks }\end{array}$} \\
\hline & & & 0 & 1 & 2 & 3 & \\
\hline 1 & $\begin{array}{l}\text { DASS } 1 \text { Saya merasa bahwa diri saya } \\
\text { menjadi marah karena hal-hal sepele. }\end{array}$ & $\begin{array}{c}1,37 \pm \\
0,81\end{array}$ & $20(14,4)$ & $58(41,7)$ & $51(36,7)$ & $10(7,2)$ & \\
\hline 2 & $\begin{array}{l}\text { DASS } 6 \text { Saya cenderung bereaksi } \\
\text { berlebihan terhadap suatu situasi. }\end{array}$ & $\begin{array}{c}1,34 \pm \\
0,79\end{array}$ & $19(13,7)$ & $63(45,3)$ & $48(34,5)$ & $9(6,5)$ & \\
\hline 3 & $\begin{array}{l}\text { DASS } 8 \text { Saya merasa sulit untuk } \\
\text { bersantai. }\end{array}$ & $\begin{array}{c}1,31 \pm \\
0,86\end{array}$ & $26(18,7)$ & $55(39,6)$ & $47(33,8)$ & $11(7,9)$ & \\
\hline 4 & $\begin{array}{l}\text { DASS } 11 \text { Saya menemukan diri saya } \\
\text { mudah merasa kesal. }\end{array}$ & $\begin{array}{c}1,32 \pm \\
0,86\end{array}$ & $23(16,5)$ & $62(44,6)$ & $41(29,5)$ & $13(9,4)$ & \\
\hline 5 & $\begin{array}{l}\text { DASS } 12 \text { Saya merasa telah } \\
\text { menghabiskan banyak energi untuk } \\
\text { merasa cemas. }\end{array}$ & $\begin{array}{c}1,29 \pm \\
0,86\end{array}$ & $25(18,0)$ & $60(43,2)$ & $42(30,2)$ & $12(8,6)$ & \\
\hline 6 & $\begin{array}{l}\text { DASS } 14 \text { Saya menemukan diri saya } \\
\text { menjadi tidak sabar ketika mengalami } \\
\text { penundaan (misalnya: kemacetan lalu } \\
\text { lintas, menunggu sesuatu). }\end{array}$ & $\begin{array}{c}1,19 \pm \\
0,85\end{array}$ & $29(20,9)$ & $65(46,8)$ & $34(24,5)$ & $11(7,9)$ & \\
\hline 7 & $\begin{array}{l}\text { DASS } 18 \text { Saya merasa bahwa saya } \\
\text { mudah tersinggung. }\end{array}$ & $1,39 \pm 0,88$ & $23(16,5)$ & $54(38,8)$ & $47(33,8)$ & $15(10,8)$ & \\
\hline 8 & $\begin{array}{l}\text { DASS } 22 \text { Saya merasa sulit untuk } \\
\text { beristirahat. }\end{array}$ & $\begin{array}{c}1,32 \pm \\
0,94\end{array}$ & $31(22,3)$ & $48(34,5)$ & $45(32,4)$ & $15(10,8)$ & \\
\hline 9 & $\begin{array}{l}\text { DASS } 27 \text { Saya merasa bahwa saya } \\
\text { sangat mudah marah. }\end{array}$ & $\begin{array}{c}1,24 \pm \\
0,89\end{array}$ & $32(23,0)$ & $\begin{array}{c}51 \\
936,7)\end{array}$ & $46(33,1)$ & $10(7,2)$ & \\
\hline 10 & $\begin{array}{l}\text { DASS } 29 \text { Saya merasa sulit untuk } \\
\text { tenang setelah sesuatu membuat saya } \\
\text { kesal. }\end{array}$ & $\begin{array}{c}1,35 \pm \\
0,93\end{array}$ & $28(20,1)$ & $51(36,7)$ & $43(30,9)$ & $17(12,2)$ & \\
\hline 11 & $\begin{array}{l}\text { DASS } 32 \text { Saya sulit untuk sabar dalam } \\
\text { menghadapi gangguan terhadap hal } \\
\text { yang sedang saya lakukan. }\end{array}$ & $\begin{array}{c}1,40 \pm \\
0,96\end{array}$ & $28(20,1)$ & $47(33,8)$ & $44(31,7)$ & $20(14,4)$ & \\
\hline 12 & DASS 33 Saya sedang merasa gelisah. & $\begin{array}{c}1,47 \pm \\
0,91\end{array}$ & $23(16,5)$ & $44(31,7)$ & $55(39,6)$ & $17(12,2)$ & \\
\hline 13 & $\begin{array}{l}\text { DASS } 35 \text { Saya tidak dapat memaklumi } \\
\text { hal apapun yang menghalangi saya } \\
\text { untuk menyelesaikan hal yang sedang } \\
\text { saya lakukan }\end{array}$ & $\begin{array}{c}1,54 \pm \\
0,87\end{array}$ & $17(12,2$ & $48(34,5)$ & $56(40,3)$ & $18(12,9)$ & \\
\hline 14 & $\begin{array}{l}\text { DASS } 39 \text { Saya menemukan diri saya } \\
\text { mudah gelisah }\end{array}$ & $\begin{array}{c}1,62 \pm \\
1,03\end{array}$ & $24(17,3)$ & $39(28,1)$ & $42(30,2)$ & $34(24,5)$ & \\
\hline & Total DASS & $\begin{array}{c}19,14 \pm \\
6,85\end{array}$ & & & & & $0-33$ \\
\hline & $\begin{array}{l}\text { Kriteria Stres Menurut DASS } \\
\text { Normal } \\
\text { Ringan } \\
\text { Sedang } \\
\text { Berat }\end{array}$ & & & $\begin{array}{l}30 \\
30 \\
55 \\
24 \\
24\end{array}$ & $\begin{array}{l}1,6) \\
1,6) \\
9,6) \\
7,2)\end{array}$ & & \\
\hline
\end{tabular}

*Catatan: DASS = Depression Anxiety Stress Scale

Tabel 3. WHOQOL-BREF dan Skor setiap domain ( $\mathrm{N}=152$ )

\begin{tabular}{clcc}
\hline No. & \multicolumn{1}{c}{ Domain } & Rata-rata \pm SD & Min-Maks \\
\hline$*$ & Kualitas hidup secara keseluruhan & $3,35 \pm 0,68$ & $2-5$ \\
$*$ & Kesehatan umum & $2,20 \pm 0,67$ & $2-5$ \\
1 & Fisik & $56,86 \pm 10,02$ & $38-88$ \\
2 & Psikologis & $54,96 \pm 11,06$ & $19-94$ \\
3 & Sosial & $55,81 \pm 14,10$ & $6-94$ \\
4 & Lingkungan & $58,77 \pm 11,12$ & $38-88$ \\
\hline
\end{tabular}




\section{Gambaran Kualitas Hidup pada Responden berdasarkan Skor setiap Pertanyaan}

Tabel 4. menunjukkan gambaran skor untuk setiap pertanyaan dalam kuesioner WHOQOL-BREF yang mengukur Kualitas Hidup rsponden dengan skor jawaban 1 sampai 5. Jumlah terbanyak untuk kategori jawaban sangat tidak puas (skor 1) yaitu pada item pertanyaan "seberapa puaskah anda terhadap diri anda" dengan jumlah responden yang menjawab yaitu 15 responden $(10,8 \%)$. Kemudian untuk kategori jawaban sangat puas (skor 5) terbanyak yaitu pada item pertanyaan "seberapa puaskah anda dengan akses anda pada layanan kesehatan " dengan jumlah responden yang menjawab yaitu 22 responden $(15,8 \%)$.

Tabel 4. WHOQOL- BREF dan Skor Setiap Pertanyaan

\begin{tabular}{|c|c|c|c|c|c|c|c|}
\hline \multirow{2}{*}{ No. } & \multirow{2}{*}{ Pertanyaan } & \multirow{2}{*}{$\begin{array}{c}\text { Rata - rata } \\
\quad \pm \text { SD }\end{array}$} & \multicolumn{5}{|c|}{ n $(\%)$} \\
\hline & & & 1 & 2 & 3 & 4 & 5 \\
\hline 1 & $\begin{array}{l}\text { Bagaimana menurut anda } \\
\text { kualitas hidup anda? }\end{array}$ & $3,35 \pm 0,68$ & $0(0)$ & $9(6,5)$ & $81(58,3)$ & $41(29,5)$ & $8(5,8)$ \\
\hline 2 & $\begin{array}{l}\text { Seberapa puas anda terhadap } \\
\text { kesehatan anda? }\end{array}$ & $3,20 \pm 0,67$ & $0(0)$ & $15(10,8)$ & $86(61,9)$ & $33(23,7)$ & $5(3,6)$ \\
\hline 3 & $\begin{array}{l}\text { Seberapa jauh masalah fisik } \\
\text { anda, mencegah anda dalam } \\
\text { beraktivitas sesuai kebutuhan } \\
\text { anda? }\end{array}$ & $2,97 \pm 0,71$ & $1(0,7)$ & $32(23,0)$ & $78(56,1)$ & $26(18,7)$ & $2(1,4)$ \\
\hline 4 & $\begin{array}{l}\text { Seberapa sering anda } \\
\text { membutuhkan terapi medis } \\
\text { untuk dapat berfungsi dalam } \\
\text { kehidupan sehari-hari anda? }\end{array}$ & $2,86 \pm 0,87$ & $4(2,9)$ & $49(35,3)$ & $51(36,7)$ & $32(23,0)$ & $3(2,2)$ \\
\hline 5 & $\begin{array}{l}\text { Seberapa jauh anda menikmati } \\
\text { hidup anda? }\end{array}$ & $3,24 \pm 0,75$ & $0(0)$ & $22(16,8)$ & $65(46,8)$ & $48(34,5)$ & $4(2,9)$ \\
\hline 6 & $\begin{array}{l}\text { Seberapa jauh anda merasa } \\
\text { hidup anda berarti? }\end{array}$ & $3,29 \pm 0,80$ & $1(0,7)$ & $18(12,9)$ & $69(49,6)$ & $42(30,2)$ & $9(6,5)$ \\
\hline 7 & $\begin{array}{l}\text { Seberapa jauh anda mampu } \\
\text { berkonsentrasi? }\end{array}$ & $3,23 \pm 0,78$ & $0(0)$ & $20(14,4)$ & $77(55,4)$ & $32(23,0)$ & $10(7,2)$ \\
\hline 8 & $\begin{array}{l}\text { Secara umum, seberapa aman } \\
\text { anda rasakan dlm kehidupan } \\
\text { anda sehari-hari? }\end{array}$ & $3,35 \pm 0,81$ & $0(0)$ & $17(12,2)$ & $70(50,4)$ & $39(28,1)$ & $13(9,4)$ \\
\hline 9 & $\begin{array}{l}\text { Seberapa sehat lingkungan } \\
\text { dimana anda tinggal (berkaitan } \\
\text { dengan sarana dan prasarana) }\end{array}$ & $3,21 \pm 0,79$ & $1(0,7)$ & $20(14,4)$ & $76(54,7)$ & $33(23,7)$ & $9(6,5)$ \\
\hline 10 & $\begin{array}{l}\text { Apakah anda memiliki } \\
\text { vitalitas yang cukup untuk } \\
\text { beraktivitas sehari-hari? }\end{array}$ & $3,21 \pm 0,84$ & $1(0,7)$ & $28(20,1)$ & $58(41,7)$ & $45(32,4)$ & $7(5,0)$ \\
\hline 11 & $\begin{array}{l}\text { Apakah anda dapat menerima } \\
\text { penampilan tubuh anda? }\end{array}$ & $3,17 \pm 0,85$ & $2(1,4)$ & $25(18,0)$ & $68(48,9)$ & $35(25,2)$ & $9(6,5)$ \\
\hline 12 & $\begin{array}{l}\text { Apakah anda memiliki cukup } \\
\text { uang untuk memenuhi } \\
\text { kebutuhan anda? }\end{array}$ & $3,20 \pm 0,72$ & $1(0,7)$ & $16(11,5)$ & $82(59,0)$ & $34(24,5)$ & $6(4,3)$ \\
\hline 14 & $\begin{array}{l}\text { kesempatan untuk } \\
\text { bersenangsenang /rekreasi? }\end{array}$ & $3,37 \pm 0,91$ & $4(2,9)$ & $15(10,8)$ & $61(43,9)$ & $44(31,7)$ & $15(10,8)$ \\
\hline 15 & $\begin{array}{l}\text { Seberapa baik kemampuan } \\
\text { anda dalam bergaul? }\end{array}$ & $2,19 \pm 0,88$ & $3(2,2)$ & $25(18,0)$ & $62(44,6)$ & $40(28,8)$ & $9(6,5)$ \\
\hline 16 & $\begin{array}{l}\text { Seberapa puaskah anda } \\
\text { dengan tidur anda? }\end{array}$ & $3,20 \pm 0,87$ & $3(2,2)$ & $22(15,8)$ & $68(48,9)$ & $36(25,9)$ & $10(7,2)$ \\
\hline
\end{tabular}




\begin{tabular}{|c|c|c|c|c|c|c|c|}
\hline \multirow{2}{*}{ No. } & \multirow{2}{*}{ Pertanyaan } & \multirow{2}{*}{$\begin{array}{c}\text { Rata - rata } \\
\pm \text { SD }\end{array}$} & \multicolumn{5}{|c|}{ n (\%) } \\
\hline & & & 1 & 2 & 3 & 4 & 5 \\
\hline 17 & $\begin{array}{l}\text { Seberapa puaskah anda } \\
\text { dengan kemampuan anda } \\
\text { untuk menampilkan aktivitas } \\
\text { kehidupan anda sehari-hari? }\end{array}$ & $3,34 \pm 0,88$ & $3(2,2)$ & $15(10,8)$ & $68(48,9)$ & $38(27,3)$ & $15(10,8)$ \\
\hline 18 & $\begin{array}{l}\text { Seberapa puaskah anda } \\
\text { dengan kemampuan anda } \\
\text { untuk bekerja? }\end{array}$ & $3,26 \pm 0,83$ & $0(0)$ & $23(16,5)$ & $69(49,6)$ & $35(25,2)$ & $12(8,6)$ \\
\hline 19 & $\begin{array}{l}\text { Seberapa puaskah anda } \\
\text { terhadap diri anda? }\end{array}$ & $2,97 \pm 1,07$ & $15(10,8)$ & $27(19,4)$ & $53(38,1)$ & $35(25,2)$ & $9(6,5)$ \\
\hline 20 & $\begin{array}{l}\text { Seberapa puaskah anda } \\
\text { dengan hubungan personal / } \\
\text { sosial anda? }\end{array}$ & $3,38 \pm 0,71$ & $0(0)$ & $10(7,2)$ & $75(54,0)$ & $45(32,4)$ & $9(6,5)$ \\
\hline 21 & $\begin{array}{l}\text { Seberapa puaskah anda } \\
\text { dengan kehidupan seksual } \\
\text { anda? }\end{array}$ & $3,26 \pm 0,71$ & $0(0)$ & $15(10,8)$ & $80(57,6)$ & $37(26,6)$ & $7(5,0)$ \\
\hline 22 & $\begin{array}{l}\text { Seberapa puaskah anda } \\
\text { dengan dukungan yang anda } \\
\text { peroleh dari teman anda? }\end{array}$ & $3,36 \pm 0,78$ & $1(0,7)$ & $13(9,4)$ & $71(51,1)$ & $43(30,9)$ & $11(7,9)$ \\
\hline 23 & $\begin{array}{l}\text { Seberapa puaskah anda } \\
\text { dengan kondisi tempat anda } \\
\text { tinggal saat ini? }\end{array}$ & $3,36 \pm 0,83$ & $1(0,7)$ & $18(12,9)$ & $61(43,9)$ & $48(34,5)$ & $11(7,9)$ \\
\hline 24 & $\begin{array}{l}\text { Seberapa puaskah anda } \\
\text { dengan akses anda pada } \\
\text { layanan kesehatan? }\end{array}$ & $3,35 \pm 0,87$ & $0(0)$ & $14(10,1)$ & $59(42,4)$ & $44(31,7)$ & $22(15,8)$ \\
\hline 25 & $\begin{array}{l}\text { Seberapa puaskah anda } \\
\text { dengan transportasi yang harus } \\
\text { anda jalani? }\end{array}$ & $3,06 \pm 0,87$ & $5(3,6)$ & $27(19,4)$ & $71(51,1)$ & $26(18,7)$ & $10(7,2)$ \\
\hline 26 & $\begin{array}{l}\text { Seberapa sering anda memiliki } \\
\text { perasaan negatif seperti } \\
\text { 'feeling blue' (kesepian), } \\
\text { putus asa, cemas dan depresi? }\end{array}$ & $3,51 \pm 0,74$ & $0(0)$ & $9(6,5)$ & $62(44,6)$ & $56(40,3)$ & $12(8,6)$ \\
\hline
\end{tabular}

\section{Hubungan Data Demografi dan Komorbid Penyakit dengan Kualitas Hidup pada Penderita DM Tipe 2}

Berdasarkan hasil penelitian pada tabel 5. Menunjukkan gambaran karakteristik responden dan komorbid penyakit yang dialami oleh penderita DM tipe 2 yang dihubungkan dengan kualitas hidup. Berdasarkan hasil uji statistik dengan menggunakan Mann Whitney, Kruskal Wallis dan Spearman Rank masing masing menunjukkan bahwa terdapat hubungan antara penyakit paru dengan domain 3 (sosial) nilai $(\mathrm{p}<0,05)$ dan terdapat juga hubungan yang signifikan antara penyakit paru dengan domain 4 (lingkungan) kualitas hidup $\quad(\mathrm{p}<0,01)$. Kemudian terdapat hubungan yang sangat signifikan antara kejadian penyakit pencernaan dengan domain 2 kualitas hidup (psikososial) dimana nilai $(\mathrm{p}<0,001)$, terdapat hubungan yang signifikan antara penyakit otot dan tulang dengan domain 3 kualitas hidup (sosial) dimana nilai $(\mathrm{p}<0,01)$ dan terdapat hubungan yang signifikan antara keterangan (penyakit lain) dengan domain 1 (fisik) kualitas hidup $(\mathrm{p}<0,001)$, dan terdapat hubungan yang signifikan antara Penggunaan obat PG dengan domain 1 (fisik) dan domain 2 (psikologis) kualitas hidup $(\mathrm{p}<0,001)$. Selanjutnya untuk data demografi tidak terdapat hubungan dengan domain pada kualitas hidup ( $p>0,01)$. 
Tampa'i, dkk.

Tabel 5. Hubungan Data Demografi dan Komorbid Penyakit dengan Kualitas Hidup pada Penderita DM Tipe 2

\begin{tabular}{|c|c|c|c|c|c|c|}
\hline \multirow{3}{*}{ Variabel } & \multirow{3}{*}{ Kategori } & \multirow{3}{*}{$\mathbf{N}$} & \multicolumn{4}{|c|}{ WHOQOL-BREF } \\
\hline & & & $\begin{array}{c}\text { Domain } 1 \\
\text { Fisik }\end{array}$ & $\begin{array}{l}\text { Domain } 2 \\
\text { Psikologi }\end{array}$ & $\begin{array}{c}\text { Domain } 3 \\
\text { sosial }\end{array}$ & $\begin{array}{c}\text { Domain } 4 \\
\text { lingkungan }\end{array}$ \\
\hline & & & $\begin{array}{c}\text { Rata-rata } \pm \\
\text { SD }\end{array}$ & $\begin{array}{c}\text { Rata-rata } \pm \\
\text { SD }\end{array}$ & $\begin{array}{c}\text { Rata-rata } \pm \\
\text { SD }\end{array}$ & Rata-rata \pm SD \\
\hline \multirow[t]{3}{*}{ Jenis Kelamin } & Laki -laki & 33 & $\begin{array}{l}58,45 \pm \\
10,67\end{array}$ & $55,48 \pm 9,67$ & $\begin{array}{l}55,79 \pm \\
12,77\end{array}$ & $59,55 \pm 11,25$ \\
\hline & Perempuan & 106 & $56,36 \pm 9,82$ & $54,80 \pm 11,50$ & $\begin{array}{l}55,82 \pm \\
14,54\end{array}$ & $58,53 \pm 11,12$ \\
\hline & p-value & & 0,36 & 0,69 & 0,82 & 0,61 \\
\hline \multirow[t]{2}{*}{ Pernikahan } & Menikah & 128 & $\begin{array}{l}56,59 \pm \\
10,18\end{array}$ & $54,95 \pm 11,37$ & $\begin{array}{l}55,88 \pm \\
14,45\end{array}$ & $58,83 \pm 11,05$ \\
\hline & $\begin{array}{l}\text { Duda/ Janda } \\
\text { p-value }\end{array}$ & 11 & $\begin{array}{l}59,91 \pm 7,71 \\
0,19\end{array}$ & $\begin{array}{l}55,09 \pm 6,78 \\
0,97\end{array}$ & $\begin{array}{l}55.00 \pm 9,49 \\
0,75\end{array}$ & $\begin{array}{l}58,09 \pm 12,37 \\
0,62\end{array}$ \\
\hline \multirow[t]{5}{*}{ Pendidikan } & $\begin{array}{l}\mathrm{TB} \\
\mathrm{SD}\end{array}$ & $\begin{array}{l}1 \\
11\end{array}$ & $\begin{array}{l}69,00 \pm 0 \\
58,09 \pm 9,38\end{array}$ & $\begin{array}{l}56,00 \pm 0 \\
54,00 \pm 11,14\end{array}$ & $\begin{array}{l}44,00 \pm 0 \\
63,09 \pm \\
13,12\end{array}$ & $\begin{array}{l}50,00 \pm 0 \\
55,91 \pm 13,16\end{array}$ \\
\hline & SMP & 23 & $55,91 \pm 8,11$ & $54,65 \pm 12,94$ & $\begin{array}{l}55,13 \pm \\
14,15\end{array}$ & $57,00 \pm 10,75$ \\
\hline & SMA & 63 & $\begin{array}{l}55,43 \pm \\
10,29\end{array}$ & $53,97 \pm 10,60$ & $\begin{array}{l}55,32 \pm \\
13,63\end{array}$ & $58,27 \pm 11,33$ \\
\hline & PT & 41 & $\begin{array}{l}58,95 \pm \\
10,59\end{array}$ & $56,90 \pm 10,78$ & $\begin{array}{l}55,29 \pm \\
14,99\end{array}$ & $61,51 \pm 10,32$ \\
\hline & p-value & & 0,28 & 0,70 & 0,41 & 0,28 \\
\hline \multirow[t]{3}{*}{$\begin{array}{l}\text { Penyakit } \\
\text { Ginjal }\end{array}$} & Tidak & 135 & $\begin{array}{l}56,96 \pm \\
10,08\end{array}$ & $54,88 \pm 11,15$ & $\begin{array}{l}55,94 \pm \\
13,85\end{array}$ & $58,61 \pm 10,96$ \\
\hline & $\mathrm{Ya}$ & 4 & $53,25 \pm 8,13$ & $57,75 \pm 8,01$ & $\begin{array}{l}51,50 \pm \\
23,44\end{array}$ & 16,70 \\
\hline & p-value & & 0,45 & 0,57 & 0,59 & 0,55 \\
\hline \multirow[t]{3}{*}{ Penyakit Paru } & Tidak & 135 & $\begin{array}{l}56,77 \pm \\
10,11\end{array}$ & $54,79 \pm 11,14$ & $\begin{array}{l}55,34 \pm \\
13,86\end{array}$ & $58,28 \pm 10,77$ \\
\hline & $\mathrm{Ya}$ & 4 & $\begin{array}{l}59,75 \pm \\
6,50\end{array}$ & $61,00 \pm 6,27$ & $\begin{array}{l}71,75 \pm \\
14,77\end{array}$ & $75,25 \pm 11,32$ \\
\hline & $\mathrm{p}$-value & & 0,46 & 0,16 & $0,04 *$ & $0,01 * *$ \\
\hline \multirow[t]{2}{*}{$\begin{array}{l}\text { Penyakit } \\
\text { Pencernaan }\end{array}$} & Tidak & 134 & $\begin{array}{l}56,83 \pm \\
10,08\end{array}$ & $54,45 \pm 10,80$ & $\begin{array}{l}55,24 \pm \\
13,75\end{array}$ & $58,39 \pm 10,87$ \\
\hline & $\begin{array}{l}\text { Ya } \\
\text { p-value }\end{array}$ & 5 & $\begin{array}{l}57,60 \pm 9,34 \\
0,79\end{array}$ & $\begin{array}{l}68,80 \pm 9,80 \\
0,00 * * *\end{array}$ & $\begin{array}{l}71,20 \pm 16,06 \\
0,03 *\end{array}$ & $\begin{array}{l}69,00 \pm 14,08 \\
0,07\end{array}$ \\
\hline \multirow[t]{2}{*}{$\begin{array}{l}\text { Penyakit Otot } \\
\text { dan Tulang }\end{array}$} & Tidak & 134 & $\begin{array}{l}56,73 \pm \\
10,07\end{array}$ & $54,88 \pm 11,20$ & $\begin{array}{l}55,33 \pm \\
14,01\end{array}$ & $58,70 \pm 11,16$ \\
\hline & $\begin{array}{l}\text { Ya } \\
\text { p-value }\end{array}$ & 4 & $\begin{array}{l}61,25 \pm 8,01 \\
0,28\end{array}$ & $\begin{array}{l}57,75 \pm 3,50 \\
0,44\end{array}$ & $\begin{array}{l}71,00 \pm 3,46 \\
0,01 * *\end{array}$ & $\begin{array}{l}61,00 \pm 10,73 \\
0,65\end{array}$ \\
\hline \multirow[t]{3}{*}{ Penyakit Lain } & Tidak & 75 & $55,24 \pm 8,57$ & $54,91 \pm 11,01$ & $\begin{array}{l}56,56 \pm \\
14,13\end{array}$ & $59,07 \pm 11,73$ \\
\hline & $\mathrm{Ya}$ & 64 & $\begin{array}{l}58,75 \pm \\
11,27\end{array}$ & $55,03 \pm 11,21$ & $\begin{array}{l}54,94 \pm \\
14,12\end{array}$ & $58,42 \pm 10,44$ \\
\hline & p-value & & 0,06 & 0,88 & 0,01 & 0,70 \\
\hline $\begin{array}{l}\text { Keterangan } \\
\text { Lain-Lain }\end{array}$ & Tidak & 75 & $55,24 \pm 8,57$ & $54,91 \pm 11,01$ & $\begin{array}{l}56,56 \pm \\
14,13\end{array}$ & $59,07 \pm 11,73$ \\
\hline
\end{tabular}




\begin{tabular}{|c|c|c|c|c|c|c|}
\hline \multirow{3}{*}{ Variabel } & \multirow{3}{*}{ Kategori } & \multirow{3}{*}{$\mathbf{N}$} & \multicolumn{4}{|c|}{ WHOQOL-BREF } \\
\hline & & & $\begin{array}{l}\text { Domain } 1 \\
\text { Fisik }\end{array}$ & $\begin{array}{l}\text { Domain } 2 \\
\text { Psikologi }\end{array}$ & $\begin{array}{c}\text { Domain } 3 \\
\text { sosial }\end{array}$ & $\begin{array}{c}\text { Domain } 4 \\
\text { lingkungan }\end{array}$ \\
\hline & & & $\begin{array}{c}\text { Rata-rata } \pm \\
\text { SD }\end{array}$ & $\begin{array}{c}\text { Rata-rata } \pm \\
\text { SD }\end{array}$ & $\begin{array}{c}\text { Rata-rata } \pm \\
\text { SD }\end{array}$ & Rata-rata \pm SD \\
\hline & Hipertensi & 20 & $\begin{array}{l}60,90 \pm \\
10,84\end{array}$ & $53,75 \pm 10,02$ & $\begin{array}{l}53,10 \pm \\
16,20\end{array}$ & $59,25 \pm 11,11$ \\
\hline & Kolestrol & 11 & $51,73 \pm 8,71$ & $50,18 \pm 12,21$ & $\begin{array}{l}54,55 \pm \\
14,00\end{array}$ & $61,00 \pm 11,83$ \\
\hline & Katarak & 6 & $52,33 \pm 9,48$ & $52,17 \pm 10,12$ & $55,17 \pm 8,30$ & $56,17 \pm 9,68$ \\
\hline & Jantung & 4 & $\begin{array}{l}73,25 \pm \\
11,84\end{array}$ & $75,00 \pm 16,26$ & $\begin{array}{l}64,00 \pm \\
20,19\end{array}$ & $67,25 \pm 9,39$ \\
\hline & Asam urat & 11 & $59,91 \pm 9,46$ & $52,82 \pm 5,77$ & $\begin{array}{l}55,09 \pm \\
13,66\end{array}$ & $55,75 \pm 8,21$ \\
\hline & Maag & 9 & $\begin{array}{l}59,78 \pm \\
10,86\end{array}$ & $57,78 \pm 8,82$ & $\begin{array}{l}58,89 \pm \\
11,28\end{array}$ & $57,11 \pm 10,63$ \\
\hline & Asma & 1 & $75,00 \pm 0$ & $56,00 \pm 0$ & $31,00 \pm 0$ & $44,00 \pm 0$ \\
\hline & $\mathrm{SNH}$ & 1 & $50,00 \pm 0$ & $69,00 \pm 0$ & $50,00 \pm 0$ & $56,00 \pm 0$ \\
\hline & Cistitis & 1 & $44,00 \pm 0$ & $56,00 \pm 0$ & $50,00 \pm 0$ & $50,00 \pm 0$ \\
\hline & p-value & & $0,00 * * *$ & 0,20 & 0,83 & 0,56 \\
\hline \multirow[t]{3}{*}{ Psi } & Tidak & 138 & $\begin{array}{l}56,95 \pm \\
10,00\end{array}$ & $55,04 \pm 11,06$ & $\begin{array}{l}55,86 \pm \\
14,14\end{array}$ & $58,79 \pm 11,15$ \\
\hline & $\mathrm{Ya}$ & 1 & $44,00 \pm 0$ & $44,00 \pm 0$ & $50,00 \pm 0$ & $56,00 \pm 0$ \\
\hline & p-value & & 0,23 & 0,33 & 0,63 & 0,89 \\
\hline \multirow[t]{3}{*}{ Psti } & Tidak & 88 & $\begin{array}{l}56,65 \pm \\
10,65\end{array}$ & $55,06 \pm 11,79$ & $\begin{array}{l}56,43 \pm \\
13,69\end{array}$ & $58,16 \pm 10,57$ \\
\hline & Ya & 51 & $57,22 \pm 8,93$ & $54,80 \pm 9,79$ & $\begin{array}{l}54,75 \pm \\
14,84\end{array}$ & $59,82 \pm 12,03$ \\
\hline & $\mathrm{p}$-value & & 0,69 & 0,79 & 0,47 & 0,56 \\
\hline \multirow[t]{3}{*}{$\mathrm{Si}$} & Tidak & 44 & $\begin{array}{l}57,93 \pm \\
10,06\end{array}$ & $55,32 \pm 11,90$ & $\begin{array}{l}54,95 \pm \\
15,91\end{array}$ & $59,80 \pm 12,33$ \\
\hline & $\mathrm{Ya}$ & 95 & $\begin{array}{l}56,36 \pm \\
10,02\end{array}$ & $54,80 \pm 10,71$ & $\begin{array}{l}56,21 \pm \\
13,24\end{array}$ & $58,29 \pm 10,54$ \\
\hline & p-value & & 0,42 & 0,79 & 0,53 & 0,68 \\
\hline \multirow[t]{3}{*}{$\mathrm{Pg}$} & Tidak & 138 & $\begin{array}{l}56,68 \pm \\
9,85\end{array}$ & $54,68 \pm 10,59$ & $\begin{array}{l}55,86 \pm \\
14,14\end{array}$ & $58,65 \pm 11,07$ \\
\hline & $\mathrm{Ya}$ & 1 & $81,00 \pm 0$ & $94,00 \pm 0$ & $50,00 \pm 0$ & $75,00 \pm 0$ \\
\hline & p-value & & $0,04 *$ & $0,01 * *$ & 0,63 & 0,18 \\
\hline
\end{tabular}

Catatan: *p <0,05 level; ** p <0,01 level; *** p <0,001 level; TB = Tidak bersekolah; SD = Sekolah dasar; SMP = Sekolah menengah pertama; SMA = Sekolah menengah atas; PSI = PSI = Peningkat Sekresi Insulin, PSTI = Penghambat sesitivitas terhadap insulin, $\mathrm{SI}=$ Suntikan insulin, $\mathrm{PG}=$ Penghambat Glukoneogenesis.

\section{Hubungan Antara Stres dan Domain Kualitas Hidup}

Tabel 6 menampilkan hubungan antara stres dan Domain Kualitas hidup. Berdasarkan hasil uji Statistik menggunakan Sperman-Rank didapatkan hasil Variabel Stres tidak memiliki hubungan ketika dikaitkan dengan semua domain kualitas hidup. Juga tidak ada hubungan yang signifikan antara domain fisik, psikologis, lingkungan, dan sosial $(\mathrm{p}<0,01)$.

Pada data demografi umur diperoleh hasil uji statistik tidak terdapat hubungan antara umur dan kualitas hidup domain 2 (sosial), domain 3 (lingkungan), dan domain 4 (Sosial). Hanya terdapat hubungan antara umur dengan domain 1 kualitas hidup (fisik) $(\mathrm{r}=-0,18, \mathrm{p}<0,01)$. Kemudian untuk durasi 
diagnosa penyakit DM tipe 2 (dalam tahun) memiliki hubungan yang sangat signifikan dengan domain 1 kualitas hidup (fisik) $(\mathrm{r}=0,25, \mathrm{p}<0,01)$.

Tabel 6. Hubungan antara Stres dan Domain Kualitas Hidup

\begin{tabular}{|c|c|c|c|c|c|c|c|}
\hline Karakteristik & 1 & 2 & 3 & 6 & 7 & 8 & 9 \\
\hline 1. Umur & 1 & & & & & & \\
\hline 2. Durasi DM Dalam Tahun & $0,28^{* *}$ & 1 & & & & & \\
\hline 3. Stress Score & $-0,20^{*}$ & $-0,06$ & 1 & & & & \\
\hline $\begin{array}{l}\text { 4. WHOQOL BREF- } \\
\text { Domain } 1 \text { (Fisik) }\end{array}$ & $0,18^{*}$ & $0,25^{* *}$ & $-0,01$ & 1 & & & \\
\hline $\begin{array}{l}\text { 5. WHOQOL BREF- } \\
\text { Domain } 2 \text { (Psikologis) }\end{array}$ & 0,00 & 0,12 & $-0,03$ & $0,31 * *$ & 1 & & \\
\hline $\begin{array}{l}\text { 6. WHOQOL BREF- } \\
\text { Domain } 3 \text { (sosial) }\end{array}$ & $-0,02$ & $-0,08$ & $-0,15$ & 0,13 & 0,14 & 1 & \\
\hline $\begin{array}{l}\text { 7. WHOQOL BREF- } \\
\text { Domain } 4 \text { (lingkungan) }\end{array}$ & $-0,09$ & 0,09 & $-0,06$ & $0,25 * *$ & $0,34 * *$ & 0,14 & 1 \\
\hline
\end{tabular}

Catatan: $* \mathrm{p}<0,05$ level; $* * \mathrm{p}$

\section{PEMBAHASAN}

\section{Gambaran Data Demografi dan Karakteristik Penyakit Responden}

Penelitian ini menunjukan bahwa rata - rata umur pasien DM tipe 258,0 tahun, umur termuda 31 tahun, sedangkan umur tertua 84 tahun. Rata-rata umur pasien pada penelitian ini sedikit lebih tua dibandingkan penelitian yang dilakukan Nauli ${ }^{11}$ dengan rata - rata 45,7. Sebuah penelitian mengatakan seseorang $\geq 45$ tahun memiliki peningkatan resiko terhadap terjadinya DM dan intoleransi glukosa yang di sebabkan oleh faktor degeneratif yaitu menurunya fungsi tubuh, khususnya kemampuan dari sel $\beta$ dalam memproduksi insulin. ${ }^{11}$

Sebagian besar responden adalah berjenis kelamin perempuan sebanyak 106 orang $(76,3 \%)$. Penyakit DM lebih banyak diderita oleh perempuan karena secara fisik memiliki peluang peningkatan berat badan, siklus bulan dan monopause juga menjadi faktor penyebab mayoritas penderita DM adalah perempuan. ${ }^{12,13}$ Perempuan dengan DM dapat mengalami penurunan kualitas hidup seperti mengalami gangguan dalam beraktivitas, mengalami perubahan peran dan perubahan kondisi fisik, hal ini akan memicu timbulnya ansietas, stres, dan depresi. ${ }^{14}$

Sebagian besar status pernikahan responden dalam penelitian ini adalah menikah 128 orang $(92,1 \%)$, sedangkan responden yang duda/janda terdapat 11 orang $(7,9 \%)$, lebih sedikit dari hasil penelitian Livana yang menemukan respondent yang sudah menikah sebanyak 23 orang (62\%) dan yang duda/janda 11 orang (30\%). ${ }^{16}$ Penderita DM yang berstatus menikah akan mempunyai harga diri yang lebih tinggi dan mempunyai sumber koping yang adekuat dari pasangannya sehingga dapat lebih mengembangkan koping yang adaptif terhadap stressor yang muncul. ${ }^{15}$

Penelitian ini didapatkan responden dengan tingkat pendidikan terbanyak ialah SMA/Sederajat dengan jumlah 63 orang (45,3\%). Tingkat pendidikan dapat mempengaruhi kemampuan dan pengetahuan seseorang dalam menerapkan pola hidup sehat, salah satunya untuk mencega terjadinya DM. Penderita DM yang memiliki tingkat pendidikan yang tinggi akan lebih matang dalam proses perubahan dirinya 
sehingga akan lebih mudah menerima pengaruh dari luar yang bersifat positif, obyektif dan terbuka terhadap berbagai informasi terkait pemahaman tentang penyakit DM, perawatan diri, dan pelaksanakan manajemen perawatan DM termasuk pelaksanaan kontrol kadar gula darah. ${ }^{16}$

Rata-rata lamanya penyakit DM diderita 6,08 tahun sedangkan hasil penelitian Shunmugam ${ }^{17}$ menemukan durasi penyakit DM 3,0 tahun. Lama waktu menderita DM tersebut menyebabkan munculnya berbagai pengalaman misalnya munculnya komplikasi DM, sehingga pasien DM tersebut termotivasi untuk patuh menjalankan diet DM, mengurangi stres, minum obat, sehingga tidak mengalami kenaikan kadar gula darah. Peneliti menarik kesimpulan bahwa lama waktu menderita DM dapat mempengaruhi perubahan dalam menerima dan menyikapi penyakit DM yang diderita. ${ }^{17}$

Terdapat tiga komorbiditas terbanyak yang termasuk dalam penyakit lainnya yaitu hipertensi, kolestrol dan asam urat. Penderita DM tipe 2 pada umumnya memiliki kondisi yang disebut dengan resistensi insulin. Insulin yang tidak bekerja tidak akan dirombak menjadi apapun dan akan tetap ada dalam bentuk insulin sehingga insulin yang berlebih inilah yang akan menyebabkan terjadinya hipertensi pada pasien DM. ${ }^{18}$

Jumlah responden yang memiliki komorbiditas kolestrol sebanyak 11 orang $(14,4 \%)$. sedangkan pada penelitian lain didapatkan jumlah responden yang mengalami kolestrol sebanyak $22(75,9 \%)$ orang dari jumlah total sampel 50 responden. ${ }^{19}$ Kadar kolestrol menyebabkan meningkatnya asam lemak bebas sehingga terjadi lipotoksisitas. Hal ini akan menyebabkan terjadinya kerusakan sel beta pankreas yang akhirnya mengakibatkan DM Tipe $2 .{ }^{20}$

Responden yang mengalami asam urat sebanyak 11 orang $(7,9 \%)$ sedangkan pada penelitian lain didapatkan jumlah responden sebanyak 12 (40\%) orang. Hal ini disebabkan oleh gangguan pada sirkulasi darah dimana resistensi insulin pada penderita DM adalah faktor utama pemicu timbulnya asam urat. ${ }^{21}$ Konsentrasi asam urat meningkat maka akan terjadi peningkatan resistensi insulin yang dapat menyebabkan timbulnya penyakit diabetes mellitus. ${ }^{22}$

Empat jenis obat yang dikonsumsi oleh responden, yaitu pemicu sekresi insulin, peningkat sensitivitas terhadap insulin, suntikan insulin dan penghambat glukoneogenesis. Dari ke empat golongan obat tersebut yang paling banyak digunakan responden ialah suntikan insulin sebanyak 95 orang $(68,3 \%){ }^{23}$

\section{Hubungan Data Kategori Faktor Demografi dan Karakteristik Penyakit terhadap Kualitas Hidup Pasien DM tipe 2}

Pada penelitian ini ditujukan pada pasien yang menderita DM tipe 2, untuk mengetahui apakah ada hubungan antara stres, serta faktor - faktor yang berhubungan dengan kualitas hidup. Data demografi terdiri dari umur, jenis kelamin, status pernikahan dan pendidikan. Adapun Hasil dari penelitian ini menunjukkan bahwa ada dan tidaknya hubungan antara jenis kelamin dan kualitas hidup yang diperoleh dari hasil uji Mann Whitney, Domain fisik ( $>00,05)$, domain psikologis $(p>0,05)$, Domain sosial $(p>0,05)$, Domain lingkungan $(p>0,05)$, dapat dikatakan bahwa tidak terdapat hubungan antara jenis kelamin dan kualitas hidup domain fisik, domain psikologis, domain lingkungan dan domain sosial. Hasil penelitian ini sejalan dengan penelitian yang dilakukan di Rumah Sakit Umum Pusat Fatmawati Jakarta menunjukan bahwa tidak terdapat hubungan antara jenis kelamin dengan kualitas hidup pada pasien DM tipe 2. Hasil penelitian ini juga menunjukan bahwa tidak terdapat hubungan yang signifikan antara pendidikan dan seluruh domain kualitas hidup ( $p>0,05)$. Pada data demografi status pernikahan tidak terdapat hubungan dengan kualitas hidup. Terkait komorbiditas penyakit ginjal dan seluruh domain kualitas hidup tidak terdapat hubungan. Berbeda dengan penelitian yang dilakukan Dewi 
(2015) bahwa terdapat hubungan antara penyakit ginjal dan kualitas hidup, karena orang yang sakit ginjal lebih teliti dalam menjada kualitas hidupnya agar tetap baik. Berbeda halnya dengan penyakit paru yang terdapat hubungan signidikan dengan kualitas hidup domain 4 (lingkungan) $\mathrm{p}>0,01$ dan domain 3 (social) $\mathrm{p}>0,04$. Penyakit kronis dapat menurunkan kualitas hidup penderita.

Pada pemberian obat tidak terdapat hubungan antara pemicu sekresi insulin dengan kualitas hidup, dikarenakan obat yang termasuk dalam golongan ini memiliki fungsi untuk mengontrol kadar gula darah yang tinggi.

Peningkat sensitivitas terhadap insulin dan suntikan insulin juga tidak memiliki hubungan dengan kualitas hidup berdasarkan hasil yang didapatkan dari nilai frekuensi lebih banyak yang menggunakan peningkat sensitivitas terhadap insulin dan suntikan insulin dibandingkan denga responden yang tidak menggunakan kedua golongan obat tersebut sehingga tidak seimbang antara jumlah pemakai dan yang tidak memakai kedua golongan obat tersebut dapat mempengaruhi penelitian ini. Penggunaan jenis obat golongan glukoneogenesis juga memiliki hubungan yang signifikan dengan kualitas hidup pendapat peneliti hal ini dapat terjadi karena responden yang menggunakan jenis obat ini hanya 1 responden yang menggunakan dari total sampel 139 jumlahnya, golongan obat ini adalah yang paling sedikit digunakan oleh responden.

\section{Hubungan Stres dan Kualitas Hidup Pada penderita DM tipe 2}

Mengenai variabel besar penelitian ini yaitu stres dan kualitas hidup pada penderita DM tipe 2 tidak memiliki hubungan dikarenakan sebagian besar hasil dari responden didapatkan stres dengan kategori sedang. Sebagian besar responden telah menderita DM tipe 2 dalam jangka waktu lama sehingga stres atau kecemasan dapat teratasi pada penderita. Dalam penelitian ini bukan hanya stres yang menjadi penyebab buruknya kualitas hidup seseorang melainkan faktor komorbiditas yang diderita responden tersebut. Misalnya pada penderita DM yang mempunyai penyakit paru yang memiliki gejala seperti sesak nafas, batuk berdahak sehingga nafsu makan responden berkurang. Faktor yang lain ialah terjadi peningkatan kadar gula dalam darah responden yang mengakibatkan glukosa akan sampai ke air kemih, dan jika terjadi peningkatan lagi makan ginjal akan membuang air tambahan untuk mengencerkan sejumlah besar glukosa hilang. Karena ginjal menghasilkan air kemih dalam jumlah yang berlebihan maka penderita DM sering berkemih dalam jumlah yang banyak.

Stres bisa memiliki konsekuensi secara fisik, emosional, intelektual, sosial dan spiritual. Biasanya akibat tercampur aduk, karena akibat yang ditimbulkan oleh stres mempengaruhi keseluruhan individu. Secara fisik, stres dapat mengancam homeostasis fisiologis individu. Secara emosional stres dapat mengakibatkan perasaan negatif atau konstruktif terhadap diri. ${ }^{24,25}$ Secara intelektual stres dapat mempengaruhi persepsi dan kemampuan memecahkan masalah. Secara sosial, stres dapat mengubah hubungan seseorang dengan orang lain. Secara spiritual, stres dapat mempengaruhi nilai dan kepercayaan individu. ${ }^{26}$

\section{KESIMPULAN}

Berdasarkan hasil penelitian ini maka dapat disimpulkan tidak ada hubungan antara stres dengan kualitas hidup pada penderita DM tipe 2 di Kabupaten Poso. Faktor-faktor yang berhubungan dengan kualitas hidup pada penderita DM tipe 2 yaitu penyakit paru, penyakit pencernaan, penyakit otot dan tulang, keterangan penyakit lainnya, dan golongan obat penghambat glukoneogenesis.

\section{UCAPAN TERIMA KASIH}

Penulis Mengucapkan terima kepada semua pihak terutama STIKES Husada Mandiri Poso yang banyak berperan dalam pendanaan penelitian ini. 


\section{DAFTAR PUSTAKA}

1. World Health Organization. World Helath Statistics 2016 : monitoring health for the SDGs sustainable developments goals. World Helath Organization. 2016.

2. Kementrian Kesehatan Republik Indonesia. Riset Kesehatan Dasar, Jakarta : Indonesia. 2013.

3. Tandra, H. Segala sesuatu yang harus anda ketahui tentang diabetes. Jakarta: PT Gramedia Pustaka Utama. 2007.

4. Nugroho, S. A. Hubungan antara Tingkat Stres dengan Kadar Gula darah Pada Pasien Diabetes Melitus Di Wilayah Kerja Puskesman Sukoharjo 1 Kabupaten Sukoharjo. Jurnal Penelitian. Surakarta: eprint.ums.ac. 2010.

5. Derek, M.I., Rottie, J. V \& Kallo, V., Darah pada Pasien Diabetes Melitus KASIH GMIM Manado. e-Journal Keperawatan, 2017. 5(1), p.2.

6. Subiyanto, P., Pengaruh Hipnorelaksasi terhadap Penurunan Tingkat Stres dan Kadar Glukosa Darah pada Pasien DM Tipe 2. Jurnal Kebidanan dan Keperawatan, 2013. 9(2), pp.163-174.

7. Widodo, A. Stress pada penderita diabetes mellitus tipe -2 dalam melaksanakan program dietdi klinik penyakit dalam RSUP Dr. Kariadi semarang. 2012. Diperoleh tanggal 15 Agustus 2014 dari http://medicahospitalia.rskariadi.co.id

8. Mandagi, A. M. Faktor yang berhubungan dengan status kualitas hidup penderita diabetes mellitus (studi di Puskesmas Pakis Kecamatan Sawahan Kota Surabaya). 2010. Diperoleh tanggal 20 September 2013 dari http://alumni.unair.ac.id/kumpulanfile/41 93836343_abs.pdf

9. Kurniawan, Y. Kualitas hidup penderita diabetes mellitus di rumah sakit umum daerah cianjur. 2008. Vol 10 No. XIII. Diperoleh tanggal 18 juli 2014 dari http://download.portalgaruda.org/article= $139603 \&$ val $=5728$

10. Suhud, M. Cuci Darah Demi Kualitas Hidup, Kompas Syb. 2009.
11. Betteng, R. Analisa Faktor Resiko Penyebab Terjadinya Diabetes Mellitus Tipe 2 pada Wanita Usia Produktif di Puskesmas Wawonasa. Jurnal eBiomedik, 2014. 2 (2), 1-9.

12. Liuw, F. F., Kandou, G.D., \& Malonda, N.S. Hubungan Antara Jenis Kelamin dan Diabetes Mellitus tipe 2 dengan Kualitas Hidup pada Penduduk di Kelurahan Kolongan Kecamatan Tomohon Tengah Kota Tomohon. Media Kesehatan. 2017. 9 (3), 1-7.

13. Wicaksono, R.P. Faktor-faktor yang Berhubungan dengan Kejadian Diabetes Mellitus Tipe 2 di Poliklinik Penyakit dalam Rumah Saki Dr.Kariadi, Diponegoro University, 2011. 1(2), 422.

14. Hasanuddin, Kristofel.,Mahatrisni., Winasis \& Satrio . Anxieties/desires: 90 insights for marketing to youth,women, netizen. Jakarta: PT Gramedia Pustaka Utama. 2011.

15. Za, N.K., \& Pramono, A. Status Gizi, Penyakit Kronis dan Konsumsi Obat terhadap Kualitas Hidup Dimensi Kesehatan Fisik Lansia. Diponegoro University, 2014. 5-39.

16. Livana, P. H., Sari, I. P., \& Hermanto, H. Gambaran Tingkat Depresi Pasien Diabetes Mellitus di Kabupaten Kendal. Jurnal Kesehatan Poltekkes Ternate, 2018. 11 (2), 48-57.

17. Nirmala, Wisnatul Izzati. Hubungan Tingkat Stres Dengan Peningkatan Kadar Gula Darah Pada Pasien Diabetes Mellitus Di Wilayah Kerja Puskesmas Perkotaan Rasimah Ahmad Bukittinggi Tahun 2015. Jurnal Ilmu Kesehatan Afiyah. 2015. http://www.ejournal.stikesyarsi.ac.id/in dex.php/JAV1N1/article/view/50

18. Sulistyoningrum, E. Tinjauan molekular dan aspek klinis resistensi insulin. Jurnal Mandala of Health. 2010. http://kedokteran.unsoed.ac.id

19. Trisnawati, S. K., \& Setyorogo, S. Faktor Resiko Kejadian diabetes 
Mellitus tipe 2 di Puskesmas Kecamatan Cengkareng Jakarta Barat tahun 2012. Jurnal Ilmiah Kesehatan. 2013. 5 (1), 611.

20. Kementrian Kesehatan Republik Indonesia. Petunjuk Teknis pengukuran faktor resiko diabetes mellitus. Jakarta: Kementrian Kesehatan Republik Indonesia. 2010.

21. Hapsari, E. G., da Costa, J. F., \& WAhyu, F.D. Pengaruh Penyuluhan tentang Pola Makan pada Penderita Diabetes Mellitus dengan dan Tanpa Komplikasi di Kecamatan Getasan. Jurnal Ilmu Kesehatan, 2017. 5 (2),8893.

22. Pradani, B. W. Hubungan Kadar Asam urat serum pada penderita diabetes mellitus tipe 2 dengan kejadian strok hemoragik di RSUD Dr. Moewardi. Universitas Muhammadiyah Surakarta. 2013.
23. Modarresnia, L., Golgiri, F., Madani. N. H., Emami, Z., \& Tanha, K. Restless legs syndrome in iranian people with type 2 diabetes mellitus : the role in quality of life and quality of sleep. Journal of clinical sleep medicine, 2018. 14 (02), 223-228. Doi.5664/jcsm.6938.

24. Ningtyas, D.W. Analisis kualitas hidup pasien diabetes mellitus tipe II di RSUD Bangil Kabupaten Pasuruan. Student Research Article, 2013.1 (1), 2-7.

25. Zainuddin, M., \& Utomo, W. Hubungan stress dengan kualitas hidup penderita diabetes mellitus tipe 2. Jurnal Online Mahasiswa Bidang Ilmu Keperawatan., 2015. 2 (1), 890-898.

26. Kozier, B., et al. Fundamental of Nursing : Concepts, Process and Practice. $\quad(7 \mathrm{t} \mathrm{h}$ ed). New Jersey: Prentice -Hall, Inc. 2004. 